\title{
What the Health Sector gains in Financial Budget 2011-12? : At Glance
}

\author{
Binita Desai and Deepak Saxena
}

Govt. Medical College, Surat, Gujarat, India

Dear Editor,

The Union Finance Minister while presenting the Union Budget for 2011-12 on $28^{\text {th }}$ February, announced to step up the plan allocations for Healthcare in 2011-12 by $20 \%$ to Rs. 26,760 crore as against Rs. 22,300 crore in the year 2010-11.

\begin{tabular}{|c|c|c|c|}
\hline \multicolumn{4}{|c|}{$\begin{array}{l}\text { Plan allocation for health care sector in different } \\
\text { financial years }\end{array}$} \\
\hline Financial year & $2009-10$ & $2010-11$ & 2011-12 \\
\hline Rs. In crore & Rs. 19,530 & Rs. 22,300 & Rs. 26,760 \\
\hline $\begin{array}{l}\text { Increase in\% compare } \\
\text { to previous year }\end{array}$ & - & $14-15 \%$ & $20 \%$ \\
\hline
\end{tabular}

The delighted news in the budget is that ministry has hiked the remuneration of two cadres of grass root workers namely Anganwadi workers (AWW) and Anganwadi helpers (AWH) who are also the backbone of Integrated Child Development Services (ICDS). ${ }^{2}$ This hike will be implemented with immediate effect from April 1, 2011 onwards. The remuneration for AWW would be increased from Rs. 1,500 per month to Rs. 3,000 per month and for AWH from Rs. 750 per month to Rs. 1,500 per month. Thus the $100 \%$ hike in remuneration is pleasuring for ICDS workers.

The budget does little to correct the inverted duty structure that the pharma sector has been complaining about. The current structure favours imports of finished dosage forms. Plus, at a time when countries like China, Israel and Taiwan are proactively promoting research and development in the pharmaceutical sector, the budget does little to boost efforts at $\mathrm{R} \& \mathrm{D}$ in this space.

The minister also announced about extension of Rashtriya Swasthya Bima Yojana (RSBY) which has emerged as an

\footnotetext{
Address for correspondence:

E-mail:drbinitadesai@yahoo.co.in; ddeepak72@yahoo.com

DOI: 10.5530/ijmedph.2.2011.17
}

effective instrument for providing a basic health cover to poor and marginal workers. The Yojana now also incorporates the unorganized sector workers in hazardous mining and associated industries like slate and slate pencil, dolomite, mica and asbestos etc. ${ }^{3}$

Reduction of import duties on specified raw material for the manufacture of syringes and needles was also declared.

With this Government now also move towards direct transfer of cash subsidy to people living below poverty line in a phased manner. Task force set up to work out the modalities for the proposed system.

The Union Budget has levied service tax on hospitals (except government hospitals) with 25 or more beds having central air conditioning facilities and diagnostic service providers and with this the end user, the patients will end up paying much more than earlier. This is detrimental to the concept of preventive healthcare and early diagnosis. ${ }^{4}$

As the infrastructure development would be beneficial to industry as it creates a more productive industrial environment and a stable liquidity and interest rate regime gain the highest The ministry announced allocation of 2,14,000 crore for infrastructure in 2011-12 which shows rise of $23.3 \%$ over last financial year and this also amounts to 48.5 per cent of total plan allocation. Though the health sectors gain the $20 \%$ increase in allocation from the previous year the actual amount of allocation was small in spite that the "Healthy man makes the Healthy Society which inturns make Healthy nation".

Feeling that perhaps the healthcare sector may now need to make an even better presentation to the government and make a better case on the long pending need to grant it a priority sector status as there were no significant changes for pharma and health industry and the budget has continued to focus on inclusive development. 


\section{REFERENCES}

1. Key Features of Budget 2010-2011 Available from URL:http://indiabudget. nic in on 02/03/2011.

2. Available from URL:http://www.moneycontrol.com/news/brokerage-recosothers/budget-2011-12-impact-sectors-that-lostgainedmost_526970.htm on date $01 / 03 / 2011$.
3. Available from URL: http: //www.equitybulls.com /admin /news2006/ news_det.asp? id=88342 on 02/03/2011.

4. Available from URL: http://www.equitybulls.com/admin/news2006/ news det.asp?id=88379 on 02/03/2011. 